症例

食道癌切除後の乳糜胸に対し OK-432 とミノマイシンによる 胸膜癒着法が奏効した 1 例

\author{
北海道大学第 2 外科（主任：加藤紘之教授), 函館共愛会病院外科* \\ 坂東幸重小田絜”伊藤清高加藤紘之
}

食道癌切除後に発生した乳糜胸に対し胸膜㾏着法が奏効した 1 例を経験した。症例は 50 歳男性で胸部中部食道癌に対し右開胸開腹食道要全摘・胸腔内リンパ節郭清・胃管形 成・胸骨後頸部食道一胃端端吻合を施行した。術後第 1 病日より $1,300 \sim 2,000 \mathrm{ml} / \mathrm{day}$ 以 上の胸腔ドレーン排液が続いた。臨床経過から乳糜胸と診断し, 保存的に経過を見てい た.しかし排液量に減少が見られないため術後第11病日に胸膜榃着法として OK-432 10 $\mathrm{KE}$, minomycin $200 \mathrm{mg}$ の胸腔内注入を行った．その直後よりドレナージが不良になっ たため 3 回の胸腔穿刺を要した. しかしこれにより排液量は減少に向かい, 術後24病日 を最後に排液はほとんど認められなくなった。その後呼吸困難, 胸痛などの自覚症状は 出現せず元気に退院した.

卖引用語：乳糜胸, 食道癌, 胸膜㾏着法

\section{緒言}

食道癌切除後の合併症の一つに乳糜胸がある。この 合併症は比較的頻度は低いものの, 確実な治療法がな いため，ひとたび発生すると致命的となることが稀で はない.

今回われわれは食道癌切除後の乳糜胸に対し OK$432 お よ ひ ゙$ minomycin（以下, MINO と略す）の胸腔 内注入による胸膜癒着法を行い，良好な結果を得たの で文献的考察を加えて報告する。

$$
\text { 症 例 }
$$

患者：50歳, 男性.

主訴：右胸部痛.

既往歴・家族歴：特記す心゙きことなし。

現病歴：1992年12月右胸部痛・嚓下障害・食欲不振 を訴え，本院内科を受診した．食道造影，食道内視鏡 検査などの結果から胸部中部食道癌と診断され，手術 目的で当科に転科入院した。

入院時現症：身長 $165 \mathrm{~cm}$, 体重 $54 \mathrm{~kg}$ と瘦せ形であ る. 理学的所見では特記すべきものはなかった。

検查所見：肺機能・心電図に異常所見は認めない。 血液生化学検査では, 血漿蛋白 $5.8 \mathrm{~g} / \mathrm{dl}$ と軽度の低蛋 白血漿を認めるほか異常所見はなかった。

1994年 5 月 9 日受付 1994 年10月26日採用
術前補助療法：術前補助療法として $40 \mathrm{~Gy} / 20 \mathrm{f}$ の放 射線照射を行った。

手術所見：1993年 2 月 2 日. 右第 5 助間の後側方切 開で開胸した，肺尖部にブラの集簇がみられた。自然 気胸を予防する目的でこれを自動縫合器を用いて切除 した。奇静脈を剥離露出し結㷊したのち切離，綎隔胸 膜を綐に開いた。食道を露出したが病変部は触知され なかった。下縦隔から上綐隔に向けてリンパ節郭清を 行ったが, 郭清中胸管の本管と思われるリンパ管を損 傷したためこれを二重結染した，食道の剥離後癌腫の 口側で食道を離断し，リンパ液の漏出のないことを碓 認して閉胸した.閉胸後, 顓部と腹部の同時操作に移っ た。食道の肛門側は噴門直下で切断し大慜側胃管を形 成し，後胸骨経路で頸部食道一胃管吻合を行った，病 理組織所見では, ImIu，a0, poorly differentiated squamous cell carcinoma, n0, ie $(-)$, ly $(-), v$ (-), aw (-), ow (-), stage Iであった（図 1).

手術後経過：手術後は翌日までレスピレーターで調 節呼吸を行った。手術時右胸腔内に留置したドレーン より，低圧持続吸引を行ったが，手術後24時間の胸腔 ドレーンからの排液は $1,200 \mathrm{ml}$ に達しその後 1 日当た ク1,500ml 以上の排液が続いたため(図 2)アルフミン


を補いつつ total parenteral nutrition（以下，TPN と 


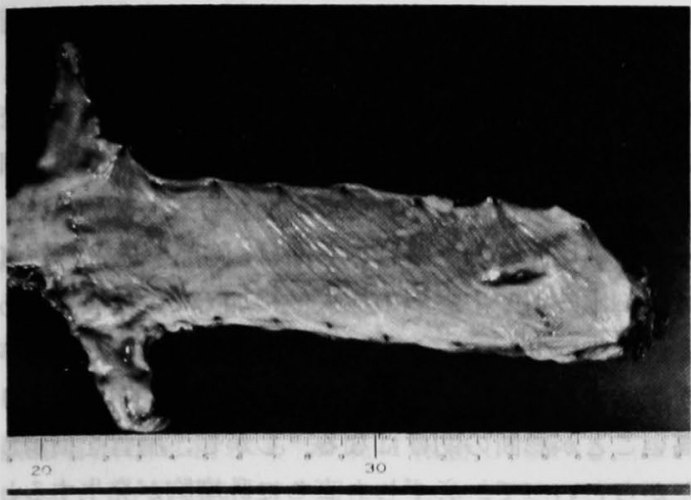

図 1 食道切除摽本：中部食道に $2 \times 1.5 \mathrm{~cm} \sigma$ 謴瘍型 てある病変を認めた。

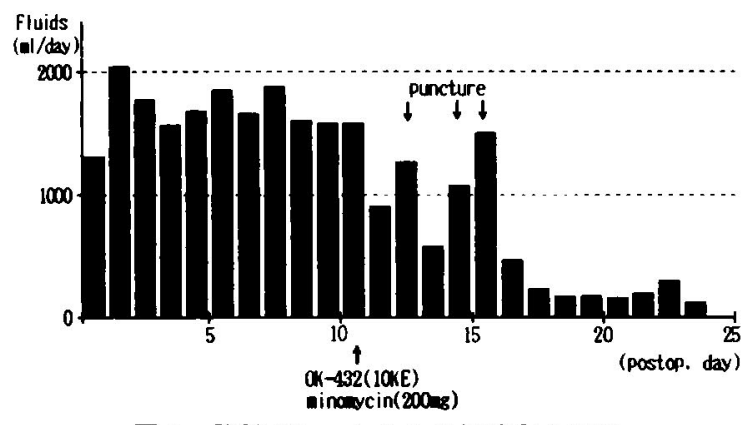

図 2 胸胿ドレーンからの排液量の推移

表 1 乳糜の成分

\begin{tabular}{l|c|c|c|c}
\hline \multicolumn{1}{c|}{ Postop. day } & \multicolumn{1}{c|}{3} & 13 & 17 & 23 \\
\hline Total protein $(\mathrm{mg} / \mathrm{dl})$ & 2.8 & 1.8 & 2.9 & 4.8 \\
\hline Triglycerid $(\mathrm{mg} / \mathrm{dl})$ & 22 & 36 & 98 & 466 \\
\hline Total cholesterol $(\mathrm{mg} / \mathrm{dl})$ & 49 & 35 & 50 & 92 \\
\hline sugar $(\mathrm{mg} / \mathrm{dl})$ & - & 115 & 77 & 119 \\
$\mathrm{Na}(\mathrm{mEq} / l)$ & 143 & 159 & 134 & 136 \\
\hline $\mathrm{K}(\mathrm{mEq} / l)$ & 4.2 & 3.4 & 4.2 & 4.0 \\
\hline $\mathrm{Cl}(\mathrm{mEq} / l)$ & 114 & $81)$ & 101 & 99 \\
\hline
\end{tabular}

略す)にて経過をみた。胸水の外観は黄色透明で，白 罣を示す乳糜の印象とは異なるが，これは絶食中で脂 肪を経口的に摄っていないためと思われた(表 1)。そ の後も胸腔ドレーンからの排液が一向に減少しなかっ たため術後第11病日に胸膜撚着による閉銷を期待し て，胸垫ドレーンから MINO 200mg，OK-432 10KE を注入した，注入直後より発熱と胸痛が見られたが，
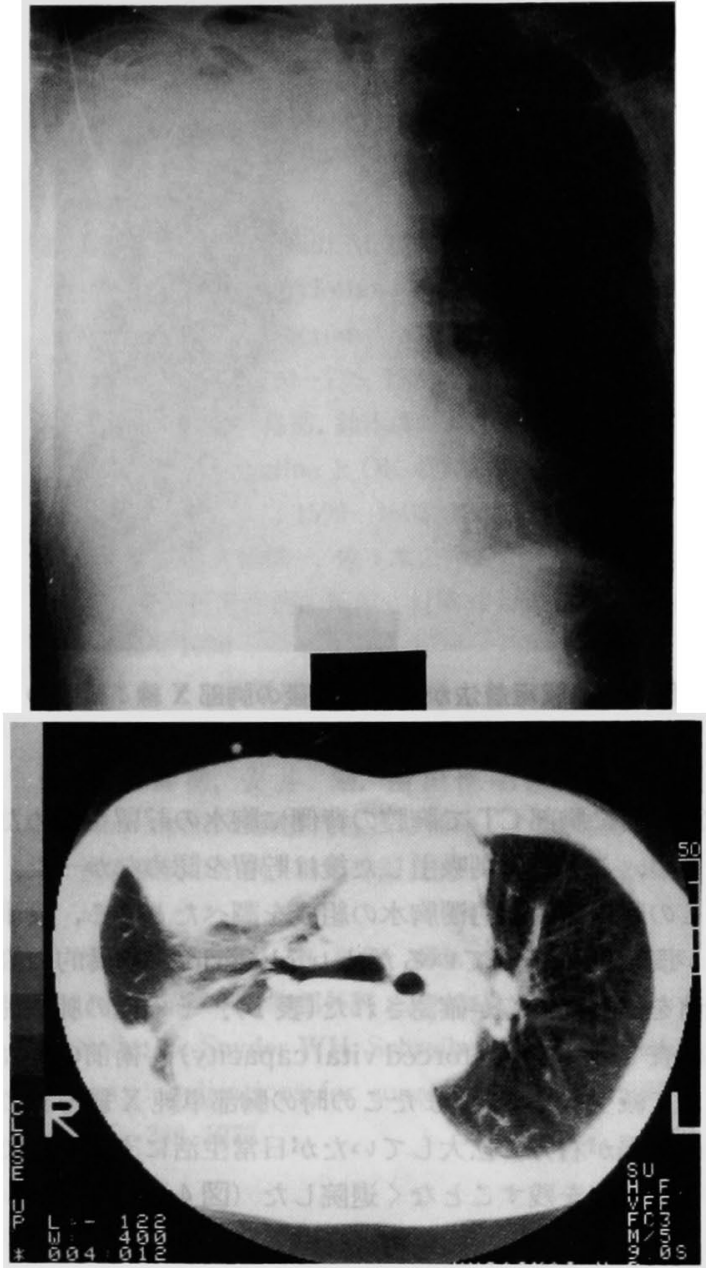

図 3 胸部単純 X 線及び胸部 CT : 術後11日目に胸膜 瘜着法を施行したところ，翌日には胸腔ドレーンか らの排液は認められなくなった。しかし胸水は数力 所に分画されて眝留していた。

消炎鎮痛剤で軽減した。その後胸水の排出は急激に減 少し，翌日には胸腔ドレーンからの排液が認められな くなった。しかし胸部 X 線写真上では, 胸腔内に多量 の乳糜が貯留しているうえ, 患者が激しい胸痛と呼吸 困難を訴えだしたため, 胸部 CT を撮ったところ臓側 胸膜と壁側胸膜との舜着が部分的なために胸水が数力 所に分画されて貯留してきていることがわかった（図 3). そのため術後第13病日に, 新しく胸腔ドレーンを 留置した。その後も胸水が部分的に貯留するたびに， 更にその部位に胸腔ドレーンを留置し，排泍量が100 $\mathrm{ml}$ 程度になったドレーンは順次抜去し良好な結果が 得られたので, 術後19日目より食事を開始した。術後 


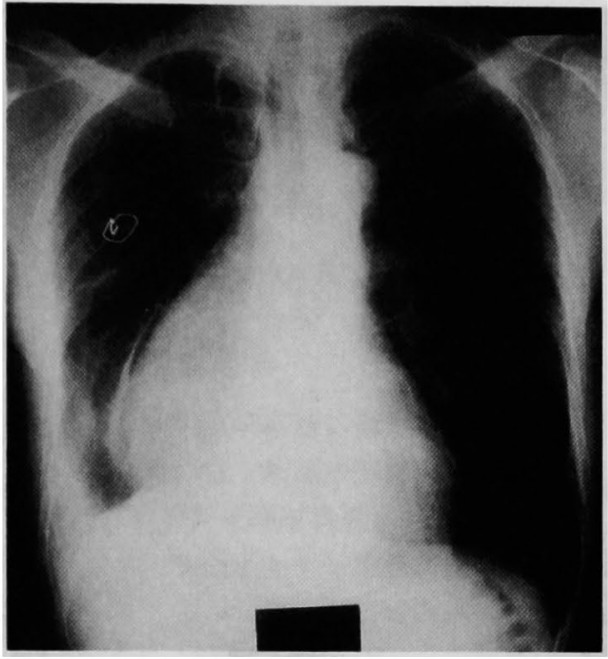

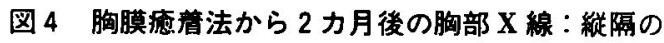
右方への抎大が見られる。

23日目に胸部 CT て胸肪の背側に胸水の貯留を認めた ため、これを穿刺吸引した後は貯留を認めなかった。 この時得られた白濁胸水の組成を調へたところ, 食事 が既に開始されているため triglycerid が特異的に高 值を示し乳糜胸が確認された(表 1)。そ後の肺機能 検查では，FVC (forced vital capacity) が術前の68\% まで減少していた。またこの時の胸部単純 X 線写真で は綎隔が右方に拡大していたが日常生活に支障をきた す合併症を残すことなく退院した（図4）.

\section{考 察}

食道癌手術後の乳糜胸の頻度は, Dougenisら”は 215 例中10例 (4.7\%), Orrigner $5^{21}$ は215例中 7 例 $(3.2 \%)$ ，石田 $5^{31}$ は 100 例中 2 例 $(2.0 \%)$, 岩桑ら 281 例中 3 例 (1.1\%) と報告しており乳糜胸の発生頻 度は約 $3 \%$ と思われる。これらの症例のうち, 乳糜胸 が原因で死亡した症例は，Dougenis らは10例中 1 例, Orrigner らは 7 例中死亡例なし, 岩桑らは 3 例中 1 例 と報告しており, 発生頻度は高くないものの, ひとた び発生すると死因となりうる.

胸管の解剖を知ることは乳糜胸を理解する上で重要 である. 鈎らの研究によると胸管の起始部は, 一般に乳 糜槽と呼ばれる膨大部から始まる。通常は第 1 腰椎体 から第 2 腰椎体の高さの腹部大動脈の右側に径が3〜 5 $\mathrm{mm}$ の乳糜槽が見出される。これから始まる胸管は腹 部大動脈の背側やや右寄りを上行し, 横隔膜の大動脈 裂孔を通り，胸部大動脈の右後方で奇静脈の左側に 沿って上行し，気管分岐部のやや下方，ほほ第 5 胸椎
の高さより，次第に向きを変えて斜めに大動脈の背側 を通過する，その後食道の左壁に沿って上行し，第 1 胸椎から第 7 頸椎にいたる高さで, 左鎖骨下動脈と左 総頸動脈の間を腹側に回り左静脈角付近で静脈に開口 する.なお胸管には多くの側副路が存在している.

食道癌切除後の乳糜胸の診断は, 胸部単純 X 線写真


るいは胸腔ドレーンからの乳糜胸特有の白濁した液体 を証明すればよい.また triglycerid が血清中の值より 高いことが診断の助けになる。しかし，胸管を損傷し たからといって，必ずしも直ちに乳糜胸が発生すると 言うわけではなく，損傷後数日以降に発生してくる場 合が多い．また，経口損取を開始していない場合，つ まり経口的に脂肪を摄取していないときには，白濁が ほとんどみられず肉眼的判別が困難なことがあり triglycerid の值も，高くならないことがある。このよ うなときにはチューフ腸㿔あるいは経口的に，牛乳か 脂肪乳剤を摄取させれば，胸水は乳白色に変化し trig lycerid の值も高くなるので診断はより確実となる.そ の他の診断法としてはリンパ管造影による胸管損傷部 の確認们やリンパ管内人の色素注入》といった方法も ある.

乳糜胸の治療は大別して胸㬶ドレナージを基本とす る保存的療法と，胸管結禁術を基本とする手術療法と がある.

手術適応に関しては Selle ら朁はまず胸腔穿刺ある いはドレナージを行い，2 週間経過しても乳糜が減少 しない場合や，1，500ml/日以上の乳糜流出が 5 日間続 く場合, あるいは栄責障害をきたす場合と述べている. またOrrigner ら $ら^{2)} 8$ 時間当たり 200〜 400ml 以上の 乳糜流出が連続 2 回続く場合には $3 \sim 5$ 日以内に手術 実施の決定をすべきだとしている，

保存的治療の要点は, 1) 貯留した乳糜液をドレナー ジして肺の膨張を保つこと,2）腸リンパ液を減少させ るため絶食あるいは低脂肪食とすること、3）乳糜流出 とともに失われる水分・電解質・蛋白質を補うことて ある.自験例では TPNを施行し,胸腔ドレーンより排 出される蛋白質は新鮮凍結血慗とアルブミン製郕で補 充していった。しかし流出してくる乳糜量は $1,300 \mathrm{ml}$ 〜2,000 $\mathrm{ml}$ 以上で減少傾向がないため, 胸膜病着を促 して乳糜漏出部の自然閉鎖をはかるへく，MINO 200 $\mathrm{mg}$ と OK-432 $10 \mathrm{KE}$ を生食 $20 \mathrm{ml}$ に溶解し胸腔内に注 入した。しかし胸膜の瘜着が一様でなく胸腔内に薬液 を注入した翌日には乳糜が胸腔内で分割されて貯留し 
た状態になった。そのため高度の胸痛と呼吸困難を訴 えたが，乳糜の販留している部位毎に胸腔ドレーンを 留置して排液することにより症状は軽快した。また乳 糜の漏出は急激に減少した。

胸膜痣着の機序としては, MINO の強酸性が胸膜中 皮細胞を刺激, 破壞し, 胸膜の symphysis を促すため とされている。 OK-432は胸膜に炎症を起こし，フィブ リンが析出し胸膜痹着が起こるとされている，食道癌 切除後の乳糜胸に対する MINO とOK-432による胸

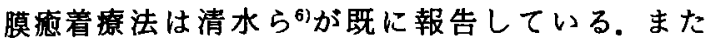
tetracyclin と OK-432を使った方法も石田ら て報告されている．しかし自験例のように不均一な胸 膜の痹着て胸腔内が分割されるといった報告はない． 本治療の副作用としては胸痛と発熱が見られるが, これは消炎鎮痛剤の投与で対処できる。しかし胸腔ド レナージ効かなくなった場合には新たに胸腔ドレーン を留置し直さなければならない。これにより胸膜瘾着 が促され，また肺の膨張も得られることから患者の呼 吸困難などの自覚症状も出現しない。本症例でも FVC に若干減少が見られたものの日常生活に支障をきたす ことはなかった。

\section{結 語}

胸膜痹着法は食道癌術後の難治性乳糜胸に対し試み るべき一方法であると考えられたが，治療の実際に当 たってはきめ細かい後療法が必要である.

\section{文献}

1) Dougenis D, Walkar WS, Cameron EWJ, et al Mnagement of chylothorax complicating extensive esophageal resection. Surgery $174: 501-$ 506,1992

2) Orrigner MB, Bluett M, Deeb GM : Aggressive treatment of chylothorax complicating transhiatal esophagectomy without thoracotomy. Surgery $104: 720-726,1988$

3）石田 萓, 森 昌造, 鈴木俊輔他：食道癌切除後の 乳哃胸 tetracycline とOK-432による癒着療法。 日消外会誌 $17: 1599-1602,1984$

4）岩桑隆三, 武藤輝一, 佐々木公一他：食道癌切除後 の乳策胸併発症例の検討. 日胸外会誌 $31: 2451$ $-2455,1990$

5）鈎スミ子：乳糜槽および胸管の外科解剖。外科 $37: 560-564,1986$

6）清水善徳, 安井昭, 西田佳昭他：OK-432, minomycin の胸腔内注入で治瘾した食道癌切除 後乳栵胸の 1 例. 日臨外医会誌 $51: 2451-2455$, 1990

7）池田道昭, 宇野 顕, 萩原 昇他：外傷性乳㿟胸の 1 手術治験例．胸部外科 $37: 543-546,1984$

8) Selle JG, Snyder WH, Schreiber JT : Chylothorax: Indications for surgery. Ann Surg 177: 245-249, 1973

\title{
A CASE OF CHYLOTHORAX COMPLICATING AFTER RESECTION OF ESOPHAGEAL CARCINOMA WHICH WAS SUCCESSFULLY TREATED BY PLEURODESIS WITH OK-432 AND MINOMYCIN
}

\author{
Yukishige BANDO, Kiyoshi ODA*, Kiyotaka, ITO and Hiroyuki KATO \\ Second Department of Surgery, Hokkaido University School of Medicine \\ *Department of Surgery, Hakodatekyouaikai Hospital
}

A case of chylothorax following esophagectomy for an esophageal carcinoma was successfully treated with pleurodesis. A 50-year-old male patient with middle intrathoracic esophageal carcinoma underwent right thoracolaparotomy, subtotal esophagectomy, intrathoracic lymph node dissection, gastroplasy and retrosternal end-to-end anastomosis. On and after the 1st postoperative day more than $1300 \sim 2000 \mathrm{ml} /$ day in volume of drainage continued through a chest tube. Considering of clinical progression, the patient was diagnosed as chylothorax. Conservative treatment was continued. As volume of the drainage did not decrease, the pleurodesis with OK-432 $10 \mathrm{KE}$ and minomycin $200 \mathrm{mg}$ was perforemed on the 11th postoperative day. After this treatment thoracosentesis was required three times, because the drainage became poor. Volume of the drainage,, however, started to decrease and almost no fluid was observed after the 24 th postoperative day. Thereafter no subjective symptoms such as dyspnea and chest pain occurred. The patient was discharged home in a good condition. 